FITRAH Jurnal Kajian Ilmu-ilmu Keislaman

Vol.03 No. 2 Desember 2017

e-ISSN : 2460-2345, p-ISSN: 2442-6997

Web: jurnal.iain-padangsidimpuan.ac.id/index.php/F

\title{
PENGEMBANGAN METODE PEMBELAJARAN PAI BERBASIS KECERDASAN MAJEMUK
}

\author{
ASNAH \\ Dosen Fakultas Tarbiyah dan Ilmu Keguruan IAIN Padangsidimpuan \\ Email: asnahray@gmail.com
}

\begin{abstract}
Learning Islamic education (PAI) is not only based on religious knowledge oriented, but also emphasized to the aspects of attitudes, values and skills/practice of religion. However, in practice in the classroom, teachers less developed all these aspects, meanwhile the students as subjects who have learning process experienced has a variety of intelligences that can be developed. In PAI learning, multiple intelligences is a grouping of capabilities in someone in order to function more optimally. For that is expected to each PAI teachers to develop teaching methods by taking various strategic measures for the purpose of learning can be achieved optimally.
\end{abstract}

Keywords: PAI Learning, religious knowledges and values, and Multiple Intelligence.

\begin{abstract}
Abstrak
Pembelajaran PAI selain berorientasi pada pengetahuan agama, juga menekankan pada aspek sikap, nilai-nilai dan keterampilan/pengamalan agama. Namun dalam pelaksanaannya guru kurang mengembangkan keseluruh aspek tersebut. Sementara dalam diri siswa sebagai subjek yang mengalami proses belajar memiliki berbagai macam kecerdasan yang dapat ditumbuhkembangkan. Dalam pembelajaran PAI, kecerdasan majemuk (Multiple Intelligences) merupakan pengelompokan kemampuan dalam diri seseorang agar dapat berfungsi lebih maksimal. Untuk itu diharapkan kepada setiap guru PAI untuk mengembangkan metode pembelajaran dengan menempuh berbagai langkah strategis agar tujuan pembelajaran dapat tercapai secara maksimal.
\end{abstract}

Kata Kunci: Pembelajaran PAI, pengetahuan agama dan nilai-nilai, dan Kecerdasan Majemuk.

\section{PENDAHULUAN}

Kebanyakan orang berpikir bahwa dengan mempunyai anak yang kecerdasan intelektualnya tinggi akan merasa aman dan yakin bahwa anak itu akan menjadi orang sukses. Dalam studi empiris yang dilakukan para pakar 
FITRAH Jurnal Kajian Ilmu-ilmu Keislaman

Vol. 03 No. 2 Desember 2017

pendidikan, bahwa untuk menjadi sukses tidak hanya cukup dengan bekal kecerdasan intelektual saja. Ternyata ada kecerdasan lain yang perlu untuk dipahami.

Kecerdasan seringkali dimaknai sebagai kemampuan memahami sesuatu dan kemampuan berpendapat. ${ }^{1}$ Dalam hal ini kecerdasan dipahami secara sempit sebagai kemampuan intelektual yang menekankan logika dalam memecahkan masalah. Kecerdasan dalam arti ini biasanya diukur dari kemampuan menjawab soal-soal tes standar di ruang kelas (tes IQ). Tes tersebut menurut Thomas R. Hoerr, sebenarnya hanya mengukur kecerdasan secara sempit karena hanya menekankan pada kecerdasan linguistik dan matematis logis saja, meski dapat mengukur keberhasilan peserta didik di sekolah, namun tidak bisa memprediksi keberhasilan seseorang di dunia nyata mencakup lebih dari sekedar kecakapan linguistik dan matematis-logis ${ }^{2}$

Meski demikian pengagungan terhadap IQ dalam menentukan kesuksesan masih mendominasi pembelajaran di sekolah dan salah satunya tampak pada penggunaan metode-metode pembelajaran tradisional, seperti ceramah dan cerita yang lebih sesuai dengan kecerdasan linguistik dan pendekatan rasional dengan logika matematika yang lebih sesuai dengan kecerdasan logis matematis. ${ }^{3}$

Bahkan pembelajaran Pendidikan Agama Islam (PAI) kebanyakan masih diisi dengan muatan hafalan, praktik ibadah ritual, dogma agama dan sejenisnya, hingga menimbulkan kesan tidak menarik, membosankan dan kurang bermakna bagi siswa yang kecerdasan linguistik dan matematisnya kurang menonjol. Siswa hanya bisa belajar dengan baik apabila materi disampaikan dengan menggunakan metode yang sesuai dengan kecerdasan mereka yang paling menonjol.

Permasalahan tersebut dapat diatasi dengan cara mengembangkan metode pembelajaran PAI dengan menerapkan teori kecerdasan majemuk, karena teori kecerdasan majemuk menghargai seluruh kecerdasan siswa, maka metode yang digunakan harus menyesuaikan dengan berbagai kecerdasan

\footnotetext{
1 Mustaqim, Psikologi Pendidikan (Semarang: Fakultas Tarbiyah IAIN Walisongo, 2004), hlm. 104.

${ }^{2}$ Thomas R. Hoerr, Multiple Intelligence, terj. Ary Nilandari (Bandung: Mizan Pustaka, 2007), hlm. 9-10.

${ }^{3}$ Paul Suparno, Teori Inteligen Ganda \& Aplikasinya Di Sek, Teori Howard G (Yogyakarta: Kanisius,2008), hlm. 6.
} 
tersebut. Dengan demikian pembelajaran menjadi bermakna dan menyenangkan.

Pembelajaran merupakan inti dari proses pendidikan, di dalamnya terjadi interaksi berbagai komponen utama, di antaranya materi, metode, dan tujuan pembelajaran serta siswa dengan guru. Untuk itu upaya mengkaji kembali pelaksanaan pembelajaran PAI di lembaga pendidikan formal semakin mendesak.

Berkaitan permasalahan di atas, sebagaimana yang disinyalir oleh Towaf dalam Muhaimin, yaitu: "Guru PAI kurang berupaya menggali berbagai metode yang mungkin bisa dipakai untuk pendidikan agama,"4 dimana siswa yang dihadapi memiliki berbagai karakteristik dan kecerdasan yang berbeda-beda.

Berangkat dari persolan di atas maka seyogyanya para guru khususnya guru PAI harus mampu mengembangkan berbagai metode dalam pembelajaran agar menghindari pembelajaran yang bersifat monoton dan menekankan pada salah satu kecerdasan saja. Dengan menggunakan teori kecerdasan majemuk ini, diharapkan siswa mampu mengenal Allah dan segenap ajaran-ajarannya serta dapat mengamalkannya secara baik dan benar.

\section{PEMBAHASAN}

\section{Teori Kecerdasan Majemuk}

Dalam perkembangan pendidikan dewasa ini, tidak hanya kecerdasan intelektual, kecerdasan emosional dan juga kecerdasan spiritual saja yang perlu dikembangkan. Namun ada beberapa kecerdasan lagi yang perlu dikembangkan sebagaimana dikemukakan dalam teori kecerdasan majemuk yang dirumuskan Howard Gardner.

Howard Gardner adalah seorang tokoh pendidikan dan psikologi yang mencetuskan teori kecerdasan majemuk atau multiple intelligences. ${ }^{5}$ Ia berkebangsaan Amerika yang lahir dengan nama lengkap Howard Earl Gardner pada tanggal 11 Juli 1943 di Scranton, Pennsilvania. ${ }^{6}$ Teori tentang Kecerdasan Majemuk ini bergema sangat kuat di kalangan pendidik karena menawarkan

${ }^{4}$ Muhaimin, Paradigma pendidikan Islam: upaya mengefektifkan pendidikan agama Islam di sekolah (Remaja Rosdakarya, 2001), hlm. 47

${ }^{5}$ Ladidlaus Naisaban, Para Psikolog Terkemuka Dunia: Riwayat Hidup, Pokok Pikiran, Dan Karya (Jakarta: Grasindo, 2004), hlm. 158-159.

${ }^{6}$ Naisaban, Para Psikolog Terkemuka Dunia: hlm.158. 
FITRAH Jurnal Kajian Ilmu-ilmu Keislaman

Vol. 03 No. 2 Desember 2017

model untuk bertindak sesuai dengan keyakinan bahwa semua anak memiliki kelebihan.?

Latar belakang munculnya teori ini adalah kritik terhadap anggapan mayoritas orang yang mengatakan bahwa intelligence quotient (IQ) merupakan penentu kesuksesan belajar dan hidup sesorang.8 Orang yang menganggap $I Q$ sebagai penentu kesuksesan seseorang cenderung berfikir bahwa orang yang paling cerdas atau juara di kelas atau sekolah adalah orang yang akan berhasil dalam hidupnya, begitu juga sebaliknya orang yang gagal di bangku sekolah maka dia tidak akan sukses dalam hidupnya. Namun kenyataan yang ada tidak demikian, sebagai contohnya adalah Bill Gates yang dianggap tidak berhasil dalam sekolahnya namun justru berhasil di bidang komputer.

Menurut Garner terdapat lebih dari satu kecerdasan manusia yang berada di luar jangkauan instrumen pengukur psikometrik standar seperti dalam tes IQ, karena dalam tes IQ sebenarnya hanya mengukur kecerdasan secara sempit yang menekankan pada kecerdasan linguistik dan matematis-logis. Menurut Thomas R. Hoerr, meski tes IQ dapat digunakan untuk mengukur keberhasilan anak di sekolah, namun tidak bisa memprediksi keberhasilan seseorang di dunia nyata (saat dia dewasa dan terjun ke dunia kerja atau masyarakat). ${ }^{9}$

Selain itu, tidak semua siswa yang diidentifikasi mempunyai kecerdasan tinggi dalam IQ standar. Hal ini cukup beralasan, karena tidak seorang pun di dunia ini yang benar-benar sama dalam segala hal sekalipun mereka kembar. Selalu terdapat perbedaan di antara mereka yang disebabkan oleh faktor genetik dan lingkungan sehingga tiap siswa merupakan pribadi tersendiri dan memiliki kekuatan khusus dalam diri mereka.

Menurut Gardner, manusia mempunyai lebih dari satu intelegensi dengan kemampuan yang berbeda yang kemudian disebutnya dengan sebutan multiple intelligence (kecerdasan majemuk). Gagasan tentang kecerdasan majemuk dimulai ketika ia melakukan penelitian mengenai "Sifat Alami dan Realisasi Potensi Manusia". Howard Gardner terinspirasi oleh buku Jean Piaget dalam bidang Psikologi Perkembangan. Jean Piaget, memandang struktur intelektual terbentuk di dalam individu akibat interaksinya dengan lingkungan.

7R. Hoerr, Multiple Intelligence, terj. Ary Nilandari, hlm. 21.

${ }^{8}$ Suparno, Teori Inteligen Ganda \& Aplikasinya Di Sek, Teori Howard G, hlm. 5.

${ }^{9}$ R. Hoerr, Multiple Intelligence, terj. Ary Nilandari, hlm. 64. 
Menurut Piaget perkembangan kognitif individu meliputi empat tahapan yaitu: 1) tahap sensory motor, 2) tahap pra operasional, 3) konkrit operasional, 4) formal operasional. ${ }^{10}$

Kecerdasan adalah kesempurnaan perkembangan akal budi (spt kepandaian, ketajaman pikiran), ${ }^{11}$ Sementara Gardner mendefinisikan kecerdasan sebagai kemampuan untuk menyelesaikan masalah, menciptakan produk yang berharga dalam satu atau beberapa lingkungan budaya dan masyarakat (intelligence has ability to solve problems, to create products, that are valued within one or more cultural). ${ }^{12}$

Pendapat yang sama dikemukakan Gunawan bahwa Howard Gardner melihat kecerdasan seseorang dalam sebuah nilai dan tes yang terstandar, ia mendefinisikan kecerdasan sebagai:

1. Kemampuan seseorang untuk menyelesaikan masalah yang ditemukan dalam kehidupan nyata.

2. Kemampuan untuk menciptakan masalah masalah baru untuk diselesaikan

3. Kemampuan untuk menghasilkan sesuatu (produk) atau menawarkan sebuah pelayanan yang dihasilkan dari kebudayaannya. ${ }^{13}$

Dari definisi tersebut berarti kecerdasan harus mengandung dua aspek yakni kemampuan berfikir abstrak dan kapasitas untuk belajar dari pengalaman yakni kemampuan memberikan respon yang tepat dalam memecahkan masalah, jadi tidak hanya diukur dari hasil tes psikologi standar seperti IQ.

Menurut Howard Gardner, semua orang unik dan semua orang memiliki caranya sendiri untuk memberikan kontribusinya bagi budaya dalam sebuah masyarakat. beliau menyatakan bahwa setiap orang memiliki semua komponen (spektrum) kecerdasan, memiliki sejumlah kecerdasan yang tergabung yang kemudian secara personal menggunakannya dalam cara yang khusus. ${ }^{14}$

Pada mulanya Howard Gardner menyatakan ada tujuh jenis kecerdasan, yaitu:

${ }^{10}$ Endang Komara, Belajar dan Pembelajaran Interaktif (Bandung: Refika Aditama, 2014), hlm. 9.

${ }^{11}$ Tim Penyusun Kamus Pusat Bahasa, Kamus Besar Bahasa Indonesia (Jakarta: Balai Pustaka, 2007), hlm. 292.

${ }^{12}$ Howard Gardner, Frames of Mind: The Theory of Multiple Intelligences (New York: Hachette UK, 2011), hlm. 10.

${ }^{13}$ Adi W. Gunawan, Born to be a Genius (Jakarta: PT Gramedia Pustaka Utama, 2012), hlm. 103-107.

${ }^{14}$ Naisaban, Para Psikolog Terkemuka Dunia, hlm. 166. 
FITRAH Jurnal Kajian Ilmu-ilmu Keislaman

Vol. 03 No. 2 Desember 2017

1. Kecerdasan bahasa atau linguistik yaitu kemampuan untuk menggunakan dan mengolah kata-kata secara efektif baik secara oral maupun tertulis.

2. Kecerdasan logika matematika yaitu kemampuan untuk menghitung, mengukur, mempertimbangkan dalilatau rumus, hipotesis, pola serta pemikiran logis dan ilmiah.

3. Kecerdasan intrapersonal yaitu kemampuan yang berkaitan dengan pengetahuan akan diri sendiri dan kemampuan untuk bertindak secara adaptatif berdasarkan pengenalan diri tersebut.

4. Kecerdasan interpersonal yaitu kemampuan untuk memahami, mengerti dan peka terhadap perasaan, intensi, motivasi, watak dan temperamen orang lain untuk membina hubungan yang efektif dengan orang lain.

5. Kecerdasan musik atau musikal yaitu kemampuan mengembangkan, mengekspresikan dan menikmati bentuk-bentuk musik dan suara.

6. Kecerdasan visual dan kecerdasan spasial yaitu kemampuan untuk mengindrakan dunia secara akurat dan menciptakan kembali atau mengubah aspek-aspek dunia tersebut.

7. Kecerdasan kinestetik yaitu kemampuan untuk menggunakan tubuh atau gerak tubuh untuk mengekspresikan gagasan atau perasaan. ${ }^{15}$

Kemudian sesuai dengan perkembangan penelitiannya pada tahun 1990an, Gardner menambahkan kecerdasan yang kedelapan dan kesembilan, yaitu:

8. Kecerdasan alamiah (naturalis) yaitu kemampuan untuk mengerti alam lingkungan dengan baik, dapat membuat distingsi konsekuensial lain dari alam natural; kemampuan untuk memahami dan menikmati alam dan menggunakan kemampuan tersebut secara produktif.

9. Kecerdasan eksistensial adalah kepekaan atau kemampuan untuk menjawab persoalan-persoalan terdalam terhadap keberadaan atau eksistensi manusia. ${ }^{16}$

Dengan mengetahui bermacam-macam kecerdasan yang dimiliki siswa, maka guru akan lebih memahami bagaimana memperlakukan siswa dengan sebenarnya. Dengan mengetahui tingkat dan jenis kecerdasan siswa, guru dapat menyesuaikan bagaimana seharusnya menyajikan pembelajaran, sehingga mereka dapat mengikutinya dengan baik.

\footnotetext{
${ }^{15}$ Gardner, Frames of Mind, hlm. 273-276.

16 Thomas Armstrong, Setiap anak cerdas!: panduan membantu anak belajar dengan memanfaatkan multiple intelligence-nya, terj. Rina Buntaran (Jakarta: Gramedia Pustaka Utama, 2002), hlm. 218-219.
} 


\section{Pembelajaran PAI dan Beberapa Masalah Mendasar}

Pembelajaran merupakan suatu kegiatan yang melibatkan seseorang dalam memperoleh pengetahuan, keterampilan, dan nilai-nilai positif dengan memanfaatkan berbagai sumber untuk belajar. Secara ideal pembelajaran di sekolah seharusnya mensinergikan antara pelajaran di sekolah dengan realitas di masyarakat. Kenyataannya siswa hanya memahami sesuatu dalam ruang yang dibatasi oleh empat dinding kelas, mengakibatkan mereka tidak bisa beradaptasi dengan kenyataan sesungguhnya di masyarakat.

Salah satu masalah yang dihadapi dunia pendidikan saat ini adalah masalah lemahnya proses pembelajaran. Dalam proses pembelajaran siswa kurang didorong untuk mengembangkan seluruh kemampuan/potensinya. Proses pembelajaran di kelas diarahkan kepada kemampuan untuk menghafal informasi, otak mereka dipaksa untuk mengingat dan menimbun berbagai informasi tanpa dituntut untuk memahami dan menghubungkannya dengan kehidupan sehari-hari. Mata pelajaran agama tidak dapat mengembangkan sikap yang sesuai dengan norma-norma agama, karena proses pembelajaran hanya diarahkan agar siswa bisa menguasai dan menghafal materi pelajaran. ${ }^{17}$

Pembelajaran pendidikan agama Islam yang selama ini berlangsung dirasakan kurang terkait atau kurang concern terhadap persoalan bagaimana mengubah pengetahuan agama yang bersifat kognitif menjadi makna dan nilai yang perlu diinternalisasikan dalam diri siswa, untuk selanjutnya menjadi sumber motivasi bagi siswa untuk berbuat dan berperilaku secara konkretagamis dalam kehidupan sehari-hari.

Sejalan dengan fenomena ini, Mochtar Buchori menilai kegagalan pendidikan agama disebabkan karena pembelajarannya hanya tertuju kepada aspek kognitif semata dari pada pertumbuhan kesadaran akan nilai-nilai agama, dan mengabaikan pembinaan aspek afektif dan konatif-volutif, yakni kemauan dan tekad untuk mengamalkan ajaran Islam. Akibatnya terjadi kesenjangan antara pengetahuan dengan pengamalan, antara gnosis dan praxis dalam kehidupan beragama. ${ }^{18}$ Pernyataan senada dikemukakan oleh Harun Nasution, bahwa pendidikan agama banyak dipengaruhi oleh trend Barat yang lebih

\footnotetext{
${ }^{17}$ Sanjaya Wina, Strategi Pembelajaran: Berorientasi Standar Proses Pendidikan (Jakarta: Kencana Prenada Media Group, 2008), hlm. 1.

${ }^{18}$ Buchori Mochtar, Pendidikan dalam Pembangunan (Yogyakarta: Tiara Wacana, 1994), hlm. 75 .
} 
FITRAH Jurnal Kajian Ilmu-ilmu Keislaman

Vol. 03 No. 2 Desember 2017

mengutamakan pengajaran dari pada pendidikan moral, padahal intisari dari pendidikan agama adalah pendidikan moral. ${ }^{19}$

Selain itu Mochtar Buchori juga mengatakan bahwa kegiatan pendidikan agama yang berlangsung selama ini lebih banyak bersikap menyendiri, kurang berinteraksi dengan kegiatan-kegiatan pendidikan lainnya. Cara kerja semacam ini kurang efektif untuk keperluan penanaman perangkat nilai yang kompleks. ${ }^{20}$ Pernyataan senada juga diungkapkan oleh Soedjatmoko sebagaimana dikutip Muhaimin bahwa pendidikan agama harus berusaha berintegrasi dan bersinkronisasi dengan pendidikan non-agama. ${ }^{21}$ Misalnya, ketika guru agama akan menyampaikan pelajaran tentang iman kepada Allah, sementara Allah itu adalah sesuatu yang gaib, yang tidak dapat ditangkap oleh indra, maka guru tersebut dapat menggunakan alam ciptaan Allah, mengingatkan siswa tentang pelajaran fisika mengenai elektron, gelombang radio, dan lainnya yang sulit ditangkap oleh indra tapi diakui keberadaannya, atau pokok bahasan tentang kekuasaan Allah, maka guru agama dapat menghubungkannya dengan pelajaran sains mengenai makhluk hidup dan alam semesta (bumi dan antariksa).

Selanjutnya kritik terhadap pelaksanaan pendidikan agama di sekolah ini datang dari seorang pakar keislaman non-tarbiyah yaitu Amin Abdullah beliau mengungkapkan sebagai berikut:

1. Pendidikan agama lebih banyak terkonsentrasi pada persoalan-persoalan teoritis keagamaan yang bersifat kognitif semata serta amalan-amalan ibadah praktis;

2. Pendidikan agama kurang konsern terhadap persoalan bagaimana mengubah pengetahuan agama yang kognitif menjadi 'makna' dan 'nilai' yang perlu diinternalisasikan dalam diri siswa melalui berbagai cara, media dan forum;

3. Metodologi pembelajaran agama tidak kunjung berubah;

4. Pendidikan agama lebih menekankan hafalan-hafalan teks keagamaan yang sudah ada;

${ }^{19}$ Harun Nasution, Islam rasional: gagasan dan pemikiran (Bandung: Mizan, 1995),

${ }^{20}$ Mochtar, Pendidikan dalam Pembangunan, hlm. 77.

${ }^{21}$ Muhaimin, Paradigma pendidikan Islam: Upaya..., hlm. 89. 
5. Sistem evaluasi, menunjukkan prioritas utama pada kognitif, dan jarang pertanyaan tersebut mempunyai bobot muatan nilai dan makna spiritual keagamaan yang fungsional dalam kehidupan sehari-hari. ${ }^{22}$

Berdasarkan kritikan para ahli di atas, dan juga fenomena yang ada, maka perlu dilakukan terobosan-terobosan, perbaikan-perbaikan, dalam rangka mewujudkan cita-cita ideal tujuan pendidikan agama. Untuk itu perlu dikembangkan berbagai metode pembelajaran dalam pembelajaran PAI ini, sehingga kegiatan pembelajaran yang masih lebih banyak terfokus pada aspek kognitif/kecerdasan intelektual dapat diubah atau diperbaiki.

\section{Pengembangan Metode Pembelajaran PAI Berbasis Kecerdasan Majemuk}

Pendidikan Agama Islam diberikan dengan mengikuti tuntunan bahwa agama diajarkan kepada manusia dengan visi untuk mewujudkan manusia yang bertakwa kepada Allah swt., dan berakhlak mulia, serta bertujuan untuk menghasilkan manusia yang jujur, adil, berbudi pekerti, etis, saling menghargai, disiplin, harmonis dan produktif, baik personal maupun sosial. ${ }^{23}$

Pendidikan Agama dimaksudkan untuk peningkatan potensi spiritual dan membentuk siswa agar menjadi manusia yang beriman dan bertakwa kepada Tuhan Yang Maha Esa dan berakhlak mulia. Peningkatan potensi spritual mencakup pengenalan, pemahaman, dan penanaman nilai-nilai keagamaan, serta pengamalan nilai-nilai tersebut dalam kehidupan individual ataupun kolektif kemasyarakatan. Peningkatan potensi spritual tersebut pada akhirnya bertujuan pada optimalisasi berbagai potensi yang dimiliki manusia yang aktualisasinya mencerminkan harkat dan martabatnya sebagai makhluk Tuhan.

Dalam pendidikan agama Islam terkandung suatu potensi yang mengacu pada dua fenomena yang berkembang yaitu:

1. Potensi psikologi dan paedagogis yang mempengaruhi manusia untuk menjadi pribadi yang berkualitas baik dan menyandang derajat mulia.

2. Potensi pengembangan kehidupan manusia sebagai khalifah di muka bumi yang dinamis dan kreatif serta responsif terhadap lingkungan sekitarnya.

\footnotetext{
${ }^{22}$ Amin Abdullah, Problem Epistemologis-Metodologis Pendidikan Islam," dalam Abd. Munir Mulkan, et.al.(ed.), Religiusitas Iptek (Yogyakarta: Pustaka Pelajar, 1998), hlm. 49-65.

${ }^{23}$ Basrudin M. Usman, Metodologi Pembelajaran Agama Islam (Jakarta: Ciputat Press, 2004), hlm. 3.
} 
FITRAH Jurnal Kajian Ilmu-ilmu Keislaman

Vol. 03 No. 2 Desember 2017

Lingkungan yang alamiah maupun yang ijtimaiah, dimana Tuhan menjadi potensi sentral berkembangnya. ${ }^{24}$

Untuk mewujudkan cita ideal tersebut, diperlukan metode pembelajaran yang tepat, agar seluruh potensi/kecerdasan yang dimiliki siswa dapat dikembangkan secara optimal. Metode pengajaran adalah suatu cara penyampaian bahan pelajaran untuk mencapai tujuan yang ditetapkan, fungsinya adalah menentukan berhasil tidaknya suatu proses pembelajaran dan merupakan bagian yang integral dalam suatu sistem pengajaran.

Menurut Abdurrahman Mas'ud, metode Pendidikan Agama Islam dalam paradigma baru harus lebih menekankan pada pengembangan kreativitas, penajaman hati nurani, dan religiusitas siswa, ini bisa dilakukan bila guru mengenal siswa lebih dekat. ${ }^{25}$

Oleh karena itu metode harus sesuai dan selaras dengan karakteristik siswa, materi, kondisi lingkungan (setting) di mana pengajaran berlangsung. Penggunaan atau pemilihan suatu metode mengajar disebabkan oleh adanya beberapa faktor yang harus dipertimbangkan antara lain: tujuan, krakteristik siswa, situasi, kondisi, kemampuan pribadi guru, sarana dan prasarana.

Secara umum seorang guru dapat mengembangkan metode pembelajaran dengan mempertimbangkan berbagai kecerdasan yang dimiliki siswa. Caranya dengan memilih metode-metode tertentu sesuai dengan tujuan pembelajaran dan inteligensi apa yang ingin dikembangkan.

Penggunaan teori kecerdasan majemuk dalam pembelajaran tidak hanya berdampak pada variasi metode saja tetapi juga pada pengaturan kelas. Kelas dapat dibuat lebih fleksibel sehingga akan memudahkan guru dan siswa dalam menggunakan beragam metode pembelajaran. Pembelajaran tidak hanya dilaksanakan di ruang kelas tertutup, tetapi dapat dilaksanakan di berbagai tempat di sekitar sekolah sesuai dengan materi yang dipelajari. Selain itu guru juga dapat mendesain kelas dengan gambar-gambar yang bervariasi sehingga ruang kelas menjadi lebih nyaman dan menyenangkan.

Dalam pengembangan metode pembelajaran berbasis Kecerdasan Majemuk (Multiple Intelligences) ada beberapa langkah yang dapat dilakukan, yaitu:

\footnotetext{
${ }^{24}$ Arifin Muzayyin, Kapita Selekta Pendidikan Islam (Jakarta: Bumi Aksara, 2012), hlm. $3-4$.

25 Abdurrachman Mas'ud, Menggagas format pendidikan nondikotomik: humanisme religius sebagai paradigma pendidikan Islam (Yogyakarta: Gama Media, 2002), hlm. 201.
} 
1. Identifikasi Tujuan Pembelajaran.

Langkah pertama yang dilakukan adalah dengan mempelajari dan menetapkan tujuan apa yang diinginkan setelah peserta didik melakukan pembelajaran. Mengenali dan menetapkan tujuan dalam pembelajaran merupakan hal yang sangat penting, sebab tujuan adalah acuan dari sebuah pembelajaran.

2. Analisis Materi Ajar.

Langkah kedua adalah menganalisis materi yang akan diajarkan. Dalam pembelajaran PAI ada beberapa karakteristik materi yang harus dikenali apakah materi tersebut merupakan konsep, prinsip, dalil, hukum, fakta ataupun prosedur. Hal ini terkait dengan bagaimana cara guru membelajarkannya agar siswa memperoleh pengetahuan, keterampilan sikap dan nilai-nilai yang terkandung dalam materi tersebut.

3. Mengenal karakteristik/kecerdasan peserta didik.

Ketika melakukan analisis terhadap berbagai pengetahuan dan keterampilan di atas, juga harus dipertimbangkan kecerdasan yang dimiliki siswa. Caranya guru bisa mengenalkan konsep kecerdasan majemuk pada siswa dengan cara membuat poster warna ukuran besar sebelum proses pembelajaran dimulai, yang berisi sembilan kecerdasan yang dimiliki setiap individu untuk merangsang dan memicu siswa untuk menyadari, mengenali serta menggali kecerdasan-kecerdasan dalam dirinya. Pada pertemuan pertama sebelum pembelajaran dilakukan guru bertanya pada siswa mengenai poster sembilan kecerdasan yang sudah dibuat berdasarkan pemahaman mereka, membuat suatu forum diskusi mengenai sembilan kecerdasan tersebut, menjelaskan serta mengajak siswa untuk membantu melaksanakan proses pembelajaran dengan cara melibatkan jenis-jenis kecerdasan yang menonjol pada dirinya.

4. Mengembangkan Metode Pembelajaran

Langkah berikutnya setelah guru menganalisis tujuan, materi dan juga kecerdasan siswa, maka guru harus menetapkan berbagai metode yang akan digunakan serta media dan tempat melakukan pembelajaran, apakah di dalam kelas atau di ruangan kelas. Misalnya, pembelajaran tentang iman kepada Allah, pembelajaran bisa dilakukan di luar kelas dengan metode tafakur alam, mengamati alam ciptaan Allah, mengenali eksistensi dirinya sebagai makhluk ciptaan Allah, menggunakan logika berpikir dengan mengaitkan alam ciptaan Allah dengan ilmu pengetahuan (science), 
FITRAH Jurnal Kajian Ilmu-ilmu Keislaman

Vol. 03 No. 2 Desember 2017

mengungkapkan kembali hasil renungannya melalui lisan dan tulisan. Melakukan gerakan (sujud syukur) atas nikmat yang telah diberikan Allah kepadanya. Sehingga muncul pribadi yang mengenal akan dirinya dan menghargai orang lain sebagai makhluk ciptaan Allah.

Pengembangan metode pembelajaran ini bertujuan untuk: 1) Mengoptimalkan potensi kecerdasan yang dimiliki oleh siswa; 2) Menjadikan kegiatan pembelajaran yang sesuai dengan tipe kecerdasan yang dimiliki oleh siswa; 3) Menjadikan kegiatan belajar menjadi lebih menyenangkan; 4) Menumbuhkan motivasi belajar PAI pada siswa; dan 5) Mengembangkan sikap positif siswa terhadap PAI.

Penerapan Model Pembelajaran Berbasis Kecerdasan Majemuk pada tiaptiap Kecerdasan: 1. Kecerdasan Linguistik dapat dilakukan dengan cara memberikan kesempatan siswa bercerita, menulis kembali yang dipelajari, dengan brain storming, dengan membuat jurnal tentang bahan, dan dengan menerbitkan majalah dinding. Dengan kata lain setelah mempelajari topik tertentu siswa perlu diberikan kesempatan mengungkapkan pemikirannya tentang bahan itu dengan menuliskan kembali dengan kata-kata sendiri. Misalnya setelah mempelajari masa kejayaan Islam, siswa diberi kesempatan untuk menceritakan kembali pengertian mereka tentang kejayaan Islam tersebut secara bebas di depan kelas. 2. Kecerdasan Matematik-logis dapat diwujudkan dalam bentuk menghitung, membuat kategorisasi atau penggolongan, membuat pemikiran ilmiah dengan proses ilmiah, membuat analogi dll. Misalnya setelah mempelajari dalil tentang ilmu Faroid, siswa diberikan soal-soal yang berbeda yang merupakan kombinasi dari rangkaian ilmu Faroid untuk dihitung dan dipecahkan. Disini perlu diperhatikan jalan pikiran dan logika siswa dalam pemecahan setiap persoalan. 3. Kecerdasan Visual-Spasial dapat diungkapkan dengan visualisasi bahan dengan membuat kaligrafi. 4. Kecerdasan Kinestetik-Jasmani dapat diungkapkan dengan ekspresi gerak dan badan. Seperti praktek sholat, wudhu, tayamum,dll. 5. Kecerdasan Musikal dapat ditumbuhkan melalui pembelajaran, dimana setiap kali sebelum guru memulai pembelajaran, beliau bisa memutar musik religius terkait dengan materi akan diajarkan. Selain itu dengan memberikan kesempatan dan tugas siswa mengaji, kegiatan nasyid atau mengungkapkan bahan ajar dalam bentuk suara. 6. Kecerdasan Interpersonal dapat diekspresikan dalam bentuk kegiatan sharing, diskusi kelompok, kerjasama 
membuat proyek atau praktikum bersama, permainan bersama maupun simulasi bersama. 7. Kecerdasan Intrapersonal dapat dikembangkan dengan memberikan waktu sendiri pada siswa untuk refleksi dan berfikir sejenak dengan mengenalkan potensi dan karakter yang dimiliki setiap individu. 8. Kecerdasan Natural dapat dibantu dengan merangsang siswa agar merasa nyaman dengan suasana alamiah seperti mengajak jalan-jalan di alam terbuka atau bisa juga dengan memutar video atau film tentang alam semesta termasuk hewan dan tumbuh-tumbuhan. 9. Kecerdasan eksistensial dapat dibantu dengan melakukan perenungan (refleksi dan tapakur alam) untuk mengenali diri dan persoalan-persoalan yang hakiki tentang manusia, setelah mengamati pemutaran video tentang penciptaan manusia, dan kajian tentang ayat alquran berkenaan dengan manusia.

\section{PENUTUP}

Kecerdasan selalu dapat dikembangkan dan dipupuk lewat pembelajaran. Disinilah pembelajaran mempunyai peranan penting, khususnya guru berperan untuk membantu perkembangan inteligensi siswa. Kecerdasan majemuk (Multiple Intelligences) siswa yang sudah tinggi dapat dimaksimalkan, sedangkan inteligensi siswa yang masih rendah dapat dibantu untuk ditingkatkan sehingga dapat menghadapi persoalan hidup yang lebih baik.

Guru seharusnya mengerti kecerdasan siswa melalui berbagai metode pengukuran intelegensi, sehingga baik dalam perencanaan, proses pembelajaran hingga evaluasi belajar, guru dapat dengan mudah untuk mengoptimalkan pembelajaran PAI. Perencanaan pembelajaran yang dipersiapkan guru sebaiknya sudah dianalisis dan disusun dengan berbagai pertimbangan baik dari sisi tujuan, materi, metode, media dan juga karakteristik kecerdasan siswa, sehingga siswa akan lebih tertarik untuk mengikuti proses pembelajaran dan seluruh potensi yang ada pada siswa dapat dikembangkan secara optimal. 
FITRAH Jurnal Kajian Ilmu-ilmu Keislaman

Vol. 03 No. 2 Desember 2017

\section{DAFTAR PUSTAKA}

Abdullah, Amin. Problem Epistemologis-Metodologis Pendidikan Islam," dalam Abd. Munir Mulkan, et.al.(ed.), Religiusitas Iptek. Yogyakarta: Pustaka Pelajar, 1998.

Armstrong, Thomas. Setiap Anak Cerdas!: Panduan Membantu Anak Belajar dengan Memanfaatkan Multiple Intelligence-nya, terj. Rina Buntaran. Jakarta: Gramedia Pustaka Utama, 2002.

Gardner, Howard. Frames of Mind: The Theory of Multiple Intelligences. New York: Hachette UK, 2011.

Gunawan, Adi W. Born to be a Genius. Jakarta: PT Gramedia Pustaka Utama, 2012.

Komara, Endang. Belajar dan Pembelajaran Interaktif. Bandung: Refika Aditama, 2014.

Mas'ud, Abdurrachman. Menggagas Format Pendidikan Nondikotomik: Humanisme Religius sebagai Paradigma Pendidikan Islam. Yogyakarta: Gama Media, 2002.

Mochtar, Buchori. Pendidikan dalam Pembangunan. Yogyakarta: Tiara Wacana, 1994.

Muhaimin. Paradigma Pendidikan Islam: Upaya Mengefektifkan Pendidikan Agama Islam di Sekolah. Bandung: Remaja Rosdakarya, 2001. https://books.google.co.id/books?id=OwGSAAAACAAJ.

Mustaqim. Psikologi Pendidikan. Semarang: Fakultas Tarbiyah IAIN Walisongo, 2004.

Muzayyin, Arifin. Kapita Selekta Pendidikan Islam. Jakarta: Bumi Aksara, 2012.

Naisaban, Ladidlaus. Para Psikolog Terkemuka Dunia: Riwayat Hidup, Pokok Pikiran, Dan Karya. Jakarta: Grasindo, 2004.

Nasution, Harun. Islam Rasional: Gagasan dan Pemikiran. Bandung: Mizan, 1995.

R. Hoerr, Thomas. Multiple Intelligence, terj. Ary Nilandari. Bandung: Mizan Pustaka, 2007.

Suparno, Paul. Teori Inteligen Ganda \& Aplikasinya Di Sek, Teori Howard G. Yogyakarta: Kanisius, 2008.

Tim Penyusun Kamus Pusat Bahasa. Kamus Besar Bahasa Indonesia. Jakarta: Balai Pustaka, 2007.

Usman, Basrudin M. Metodologi Pembelajaran Agama Islam. Jakarta: Ciputat Press, 2004. 
Wina, Sanjaya. Strategi Pembelajaran: Berorientasi Standar Proses Pendidikan. Jakarta: Kencana Prenada Media Group, 2008. 
FITRAH Jurnal Kajian Ilmu-ilmu Keislaman

Vol. 03 No. 2 Desember 2017

\section{Urgensi Penelitian dalam Keberhasilan Dakwah}

Drs. Hamlan, MA

Dosen Fakultas Dakwah dan Ilmu Keguruan IAIN Padangsidimpuan 